\title{
Corporeal Vulnerability and the Temporality of Feminist Theory
}

\section{by Emily Cousens}

\begin{abstract}
In recent years, Judith Butler has been credited with advancing a 'theory' of vulnerability that addresses the concerns of previous articulations of the concept within feminist thought. This article will closely elucidate Butler's presentation of this term, distinguishing it from other proximately related terms in her work: precarity and precariousness. It will then proceed to level two, related, criticisms at what is a highly important contribution to contemporary feminist thought. First, it will argue that the emerging discourse of vulnerability within feminism tends to present there as being an 'old' and 'new' formulation of the concept, that correspond to 'bad' and 'good' respectively. I will argue that such an approach is emblematic of the 'progress narrative' within much feminist academia, where authors are compelled to situate themselves against their forbearers. This leads to the second criticism: that this process of dismissing past feminist reflections on vulnerability has led to a lacuna in feminist thought regarding the possibility of theorising sexual violence.
\end{abstract}

\section{i. Corporeal Vulnerability}

In her recent work, Judith Butler develops an account of 'corporeal vulnerability' that has been highly acclaimed by philosophers, feminist and otherwise. It is of particular significance for those interested in vulnerability because, in recent years, it appears to be emerging as an improved and authoritative account of vulnerability. Gutterman and Rushing for example, have hailed the possibility of its uptake as 'politically revolutionary' (in Carver and Chambers 2008: 138). Accordingly, I will detail Butler's account of the concept here, before cautioning against receiving it as a new, exhaustive elaboration of the term.

It is in Precarious Life (2004a), that Butler first refers to corporeal 
vulnerability, when she asks her reader:

What politics might be implied by staying with the thought of corporeal vulnerability itself, a situation where we can be vanquished or lose others. Is there something to be learned about the geopolitical distribution of corporeal vulnerability from our own brief and devastating exposure to this condition? (2004a: 29).

Whilst she has developed accounts of vulnerability before: Linguistic Vulnerability in Excitable Speech (1997a), and Primary Dependency in The Psychic Life of Power (1997b), and one critic even argues that vulnerability is Butler's 'abiding concern' (Shulman 2011: 229), in Precarious Life Butler begins to outline a specifically ethical account of the concept, in the form of corporeal vulnerability.

That the term first emerges as Butler is reflecting on the United States' violent response to $9 / 11$ and the unending War on Terror that ensued is significant. In the face of a foreseeable cycle of retributive violence, Butler is looking for a basis for ethics that can provide a lens through which to see the world differently, hence the books dedication: 'For Isaac, who imagines otherwise'. In posing this question to her readers, Butler is asking them to reflect on the vulnerability that the United States (both a subject in its own right and a collection of psyches), was painfully awakened to in the aftermath of the 2001 terror attacks. From the realization that the self can be impinged on by another comes the potential for a collapse of the atomized self-Other distinction.

That US boundaries were breached, that an unbearable vulnerability was exposed, that a terrible toll on human life was taken, were, and are, cause for fear and mourning; they are also instigations for patient political reflection (2004a: xi).

In the face of violence, and even violation then comes the possibility for a shattering of the sovereign subject.

Butler presents corporeal vulnerability as the condition that can unite subjects. It is located simply in the 'fundamental sociality of embodied life' and therefore is a product of subjects' inevitable, undeniable and ineliminable interdependence. Butler says that 'in a way, we all live with this particular vulnerability, a vulnerability that is part of bodily life' (2004a: 2829 ) and thus corporeal vulnerability follows from the fact of embodied, relational existence. 
As Butler understands it, we are all potentially inflicted upon by others and vice versa, and thus what constitutes our selfhood is that we exist as a site of intersubjective ties to others. This is revealed in the occasion of violence. Yet the United States abandoned mourning after just ten days, and thus 'was missing the opportunity to redefine itself as part of a global political community' (2004a: xi). Corporeal vulnerability figures as an underlying condition of all subjects' (once again nation and psyches in this context, but by no means limited to them) existence, and one that provides the possibility for recognising and thus rethinking our ties to others. Butler appeals to it in this text because she thinks that 'mindfulness of this vulnerability can become the basis of claims for non-military political solutions' (2004a: 29). The very fact that we are susceptible to violence provides the condition for non-violence, and the motif of corporeal vulnerability operates as that which enables us to imagine a peaceful global political community in place of the current system of warring sovereign states.

\section{ii. Grief Mourning and Loss}

Butler first speaks about corporeal vulnerability in the context of the terror attacks of September 11th because, for her, an encounter with the contiguous experiences of violence, grief or loss provide the occasion to reflect on our constitutive vulnerability and our common humanity. ${ }^{1}$ These correlative encounters reveal to us that 'we can be vanquished or lose others' and consequently our ties to and dependence upon one another become evident. Human self-realization flows from these experiences: 'grief contains the possibility of apprehending a mode of dispossession that is fundamental to who I am' (2004a: 28). In such an experience 'something about who we are is revealed, something that delineates the ties we have to others, that shows us that these ties constitute what we are, ties or bonds that compose us' (2004a: 22). Accordingly, these transformative experiences 'challenge the very notions of ourselves as autonomous and in control' (2004a: 23) and may open us up to others.

Butler is posing a subject of ethics that challenges the liberal notion of the sovereign individual. When we undergo these experiences, it becomes apparent that 'we're undone by each other' (2004a: 23), in the case of loss for example 'I think I have lost "you" only to discover that "I" have gone missing as well' (2004a: 22). For Butler, loss, mourning and grief are key ethical experiences because they highlight to us our constitutive relationality and coextensively, our constitutive vulnerability. Hence, we are vulnerable because we are interdependent: 'One insight that injury affords is that there 
are others out there on whom my life depends, people I do not know and may never know'. Moreover, what follows from this is a strong ethical claim: 'apprehension of our commonality' (2004b: 25) can serve as the possibility for a global community. Grief and Loss not only highlight our constitutive dependence on those that we know and love; but also for Butler, to the global political community. 'Many people think that grief is privatizing, that it returns us to a solitary situation. But I think it furnishes a sense of political community of a complex order, and it does this first of all by bringing to the fore the relational ties that have implications for theorizing fundamental dependency and ethical responsibility' (2004a: 22). At exactly the same time that we become aware of what makes us humans, we become aware of what unites us as humans. We are 'returned to a sense of human vulnerability, to our collective responsibility for the physical lives of one another' (2004b: 23). As such grief and loss are the experiences that enable us to reflect on our embodied interdependence. They facilitate recognition which 'has the power to change the meaning and structure of the vulnerability itself' (2004a: 43). It is through recognition of one another's vulnerability that humanization occurs, and this in turn provides the basis for far reaching ethical obligations.

Vulnerability on this account is not negative but ambivalent. We are all 'vulnerable to violence; but also vulnerable to another range of touch, a range that includes the eradication of our being at one end, and the physical support for our lives at the other' (2004a: 31). Importantly, vulnerability is more closely understood as responsiveness and openness than susceptibility to harm.
All responsiveness to what happens is a function and effect of vulnerability- of being open to a history, registering an impression, or having something impressed upon one's understanding. Vulnerability may be a function of openness that is of being open to a world that is not fully known or predictable (2015: 149).

Thus Butler's corporeal vulnerability amounts to a complete reformulation of the concept from those that speak of vulnerability as a negative condition. Rather, corporeal vulnerability emerges as the non-negotiable fact of embodied existence. Whilst most of the time we, like the United States did, may presume that we are bounded, invulnerable individuals, this is a mistake. Butler insists that 'although we may legitimately feel that we are vulnerable in some instances and not in others, the condition of our vulnerability is itself not changeable' (2015: 150). And this mistake is one that we are forced to contend with when we undergo experiences of violence, 
loss, grief and mourning.

\section{iii. Vulnerability, Precariousness, Precarity}

Vulnerability is supplemented by two distinct yet converging concepts; precarity and precariousness. In Frames of War, a book that Butler herself describes as returning 'in different ways to common themes' (2010: ix) to those of Precarious Life, the distinction between precariousness, precarity and vulnerability is elucidated. Birgit Schippers points out that the vulnerability of Precarious Life has two interpretations which must be separated:

The challenge [...] lies with drawing the distinction between existential forms of vulnerability, which constitute a point of departure for political life, and concrete and specific forms of vulnerability that are the product of power (2014: 34).

Precariousness and precarity for Butler perform precisely this role as she explains: 'The more or less existential conception of 'precariousness' is thus linked with a more specifically political notion of 'precarity' (2010: 3). Precariousness is thus a generalized human condition, whereas precarity is contingent; a product of political arrangements. Butler explains:

Precariousness and precarity are intersecting concepts. Lives are by definition precarious: they can be expunged at will or by accident; their persistence is in no sense guaranteed. In some sense, this is a feature of all life, and there is no thinking of life that is not precarious- except, of course, in fantasy, and in military fantasies in particular. Political orders, including economic and social institutions, are designed to address those very needs without which the risk of mortality is heightened. Precarity designates that politically induced condition in which certain populations suffer from failing social and economic networks of support and become differentially exposed to injury, violence and death (2010: 25).

Thus life is precarious, and precarity is the differential distribution of this condition, a product of contingent power relations that render some lives more valuable than others.

The introduction of these intersecting concepts, complicates the reading of vulnerability as the fact of embodied interdependent existence as it becomes necessary to distinguish it from these other terms. Precarity, as a 
politically induced, unevenly distributed condition is easily separated from corporeal vulnerability which, as we have seen, is an underlying fact of human existence. In contrast precarity is 'the particular vulnerability imposed on the poor, the disenfranchised, and those endangered by war or natural disaster' (Watson 2012) whose deaths go unacknowledged. The victims of the American military in the war on terror, as well as those who lost their lives to AIDS in the 80s and 90s figure here.

Precariousness, however, is less easy to distinguish from vulnerability. Erinn Gilson remarks 'these concepts seem quite similar, indistinct even' (2014: 47); both appear to be the underlying fact of subjects' existence. Butler says that precariousness 'is co-extensive with birth itself (birth is by definition precarious)' (2010: 14) and 'it can only be that life, conceived as precarious life, is a generalized condition'. Moreover, just as with vulnerability 'under certain political conditions it [precariousness] becomes radically exacerbated or radically disavowed' (2010: 48). The overlap is indeed significant. Gilson proceeds to distinguish them by observing that 'vulnerability is a more general notion than precariousness, with a broader scope and application' (2014:46). For her, precariousness 'pertains only to life whereas other things can be regarded as vulnerable' (2014: 46). Specifically, 'we are vulnerable not only because we are living, embodied beings but also because of the way in which we occupy a social world ordered by given norms (for recognition, intelligibility, acceptability, and so on)' (2014: 46). Thus, vulnerability is more intimately connected with normativity, in fact 'the relation between vulnerability and normativity is constitutive' (Gilson 2014: 47).

I think Gilson is correct here that vulnerability is more intimately connected with normativity than precariousness and that precariousness refers to life. However, the distinction that Gilson makes between being vulnerable qua embodied being and vulnerable qua occupant of a social world ordered by norms is misleading: embodiment and normativity cannot be distinguished, let alone prioritised, in this way. For Butler, it is as bodies that we are vulnerable: 'the body is a social phenomenon: it is exposed to others, vulnerable by definition' (2010: 33). Throughout Butler's thought, the body figures as a discursively constructed and contingent entity. This stands in contrast to lives which are material realities to the extent that 'they can be expunged at will or by accident; their persistence is in no sense guaranteed' (2010: 25). Thus, as I understand it, the distinction between vulnerability and precariousness is a distinction between their discursive and material referents, where material life is understood as the world of effects and discursive life is the ongoing process of construction. The body for Butler is vulnerable because of its constitutive sociality. It is 'as something that, by 
definition, yields to social crafting and force' that 'the body is vulnerable' (2010: 33). Hence bodies are produced in and through normative frameworks. Lives on the other hand are significant because of their finitude, something that renders them more fragile than bodies. By locating a common vulnerability in the body however, I will argue that Butler risks obscuring the different ways in which bodies are culturally coded as vulnerable and violable, and frequently rendered such.

\section{iv. Corporeal Vulnerability and Feminism}

This conceptualisation of vulnerability has caught the attention of many feminists because of its universal, yet neither essentialising nor prescriptive reach. Butler says 'Despite our differences in location and history, my guess is that it is possible to appeal to a "we" for all of us have some notion of what it is to have lost somebody. Loss has made a tenuous "we" of us all' (2004a: 20). As Danielle Petherbridge explains, vulnerability, accessed through experiences such as loss, functions as a weak universal (2016: 593). There are very few things that we can say about the human without making a normative and exclusionary claim. But for Butler, we are the all same in being bound to and dependent upon one another. Hence she provides us with a humanism as the basis for her global ethics, but one that manages to be inherently inclusive. Rather than the category of 'human' being delimited by certain attributes it is based on the interdependency of subject formation.

This is clearly an extremely welcome contribution into a context in which the feminist contentions of the 1990s were by and large won by the postmodernists and the demise of the universal subject quickly ensued. As identity politics were disregarded, the transformative impulses of the second wave 'were channelled into a new political imaginary that foregrounded 'difference" (Fraser, 2013: 1). The reason for this shift is well-known: the category of woman had been exclusionary and essentialising, and thus the possibility of a future for feminism lay in its demise (Riley 1988). This was coupled with the reassurance that 'attending to differences is the means to craft a critical project and analytic perspective that does not exclude' (Weigman, 2012: 68). However, for those with normative aspirations, the rejection of universalism that the postmodern perspective corresponded to, appeared to lead to an impasse. Many people shared Seyla Benhabib's concern that universalism and normativity were being challenged just as they were needed more urgently:

universalism has fallen on hard times [...] Yet paradoxically, the political realities of our time - ranging from ethnic cleansing 
and mass rapes of Muslim women in Bosnia to the crushing of the democratic opposition in Tiananmen Square in China and to the defence of civil and political rights of all minorities in the successor states of the former Society Union- have placed the necessity for universalist ideals on the global agenda (1994: 173).

Thus Butler's postulation of an inherently inclusive yet universally applicable concept, that can provide a basis for ethics and which has normative implications and prescriptions has been described by feminist philosopher Susan Hekman as 'a-or perhaps the- central ethical issue of our time' (Hekman 2014: 453). As well as being philosophically sophisticated, predicating an ethics on vulnerability has specifically feminist merits as well. As we have seen, it counters the masculine norms of independence and autonomy that have tended to govern Western philosophy. To say that 'I am vulnerable' is not to make a claim about my particular individual situation but rather to make a claim about my connection to those across the globe. Butler is outlining 'a principle of equal vulnerability that governs all living beings' (2009: xvi), that emanates from the body. Hence the brilliance of Butler's corporeal vulnerability is that it provides a minimal basis of ethics that can apply to any living being at any time or place and it does all this whilst undermining the traditional masculinist subject of philosophy.

\section{v. Corporeal Vulnerability: A Progress Narrative}

Despite being a highly important contribution to recent theory, there are two related problems with Butler's account of vulnerability for feminism. The first pertains to its reception, the second to its depoliticised nature.

As we have seen, Butler's account of vulnerability has been welcomed by many currently writing on the topic Ann Murphy summarises the mood within feminism:

In the past, vulnerability has figured as a liability that plagues women disproportionately. Women's embodied vulnerability to various types of sexual violence and oppression has been figured as a liability in need of redress. In the last decade, however, a different feminist position on vulnerability has emerged, one that looks to the experience of vulnerability for what it may provide in terms of ethical and political provocation (2011: 67). 
Thus Butler's account of vulnerability is being received within feminist thought as a new, improved formulation of a hitherto thorny concept Murphy goes on to describe the present feminist engagement with vulnerability as 'redemptive and aspirational', 'a resurrection'. Feminists are now free to return to the concept anew, over and against 'the past, where women's exaggerated vulnerability to sexual violence served as the principal locus of redress' (2011: 70). According to Murphy's reasoning, vulnerability has a clear history within feminist theory: in the past women were passive and vulnerable, men active and violating. Now, vulnerability figures as the ground of both the ethical subject and our ethical obligations.

The problem with such a characterisation however, is that it constructs a 'progress narrative', where the past figures as the point of departure for a new, improved, enlightened present. Clare Hemmings, reflecting on the ubiquity of such chronological approaches to storytelling explains how they serve to 'position their teller as a heroine of the past, present and future of Western theory' (2011: 5). Receiving Butler within such a progressive history then, serves to immediately lead her account to be awarded paradigmatic status, warranting a lack of engagement with contributions that came before.

Progress narratives are clearly problematic in and of themselves. Temporal succession becomes misconstrued as historical supersession and a Hegelian logic situates the past as merely instrumental. This linear history has a specifically feminist manifestation, as Victoria Browne laments: 'feminist work produced in the 1970s is consigned to the 'dustbin of history', and frequently dismissed without even being read' (2014: 10). Whilst Murphy and none of the contemporary feminist philosophers of vulnerability name their ignorant forebears, as Clare Hemmings spells out: 'you may know without me telling you that "the past" most often refers to the 1970s' and that contributions from this period were 'naïve and essentialist' (2011: 5). As a result, 'the radical feminism of the 1970s in particular has become synonymous with everything "bad" or embarrassing about feminism: a phase that feminism has grown out of' (Browne 2014: 10). The reception of Butler's work by Murphy as 'redemptive and aspirational' then amounts to a progress narrative within which a straw man figure of 'the past' is constructed against which contemporary contributions assume ameliorative status.

Butler herself participates in this teleological construction. Whilst she recognises that 'the value of vulnerability has been important to feminist theory and politics' (2015: 142), she cautions against a feminist analysis of 'women's bodies as particularly vulnerable' as this immediately takes us back to 'the long and lamentable gender politics that allocates the distinction between passive and active to women and men respectively' (2015: 139). This 
makes it easy for critics to interpret her as offering a novel account of a concept for feminism that can relieve the concerns of yesteryear. Erinn Gilson offers such a commendation, praising Butler's move away from a 'reductively negative' theorisation to a 'more substantial and nuanced account of the nature of vulnerability, which can allay some of the concerns about an ethics of vulnerability' (2014: 6). In other words, the dominant 'reengagements' with vulnerability within feminism all assume the spectre of an unsophisticated antecedent that serves to delineate the bounds of acceptability today.

\section{vi. Vulnerability and Sexual Violence}

Vulnerability is associated with the 1970s because of the politics of sexual violence that was prominent at the time. Kate Millet's ground-breaking PhD thesis Sexual Politics was published in 1970 and half way through the decade Susan Brownmiller's Against Our Will: Men, Women and Rape was released to high acclaim. The decade was characterised by women's activism against rape, domestic violence and pornography. In the UK the First Women's Liberation march took place in 1971 and the first Women's Aid federation was set up in 1974: the charity led the way in campaigning for the Domestic Violence and Matrimonial Proceedings Act of 1976, which provided legal protection to female victims of domestic violence. Meanwhile in the US, New York Radical Feminists (NYRF) and Women Against Porn (WAP) organised around the idea that men consciously maintained power over women and that women across society had internalised, through gender roles, their own subordination. Whilst vulnerability was not necessarily central to any of the theories that motivated this 'wave' of activism, a foundational notion of women as vulnerable in the sense of susceptible to harm clearly underscored this politics.

However, as we have seen the 1970s are also understood to be naïve and essentialising, embarrassing and victimizing. Thus within the logic of the progress narrative the subject matter of the 1970s and the philosophical approaches (as they are remembered) become equated. Understanding vulnerability as susceptibility to harm becomes immediately essentialising and victimising and to engage in a politics of sexual violence is to risk essentialism.

Reflecting on the 'lacuna' with regard to feminist scholarship on rape, Carine Mardossian asks 'how the radical and revolutionary women of the 1970s whose activism has remained unparalleled in the history of second and third wave feminisms have come to represent "victimhood" two decades later'? She reminds readers that 
the 1970s were a time when women suffering from domestic and sexual violence - that is forms of violence that were not yet identified as crimes - started demonstrating in mass against rape and battery. The movement's examination of the destructive effects of power on women's psyches could therefore not be divorced from these waves of feminist activism that were sweeping the country. In such a context, being a victim did not mean being incapacitated and powerless. It meant being determined and angry (although not a pathologically resentful) agent of change (2002: 767).

However, such a historical context is absent from the present reflections on vulnerability, and consequently an entire body of work is dismissed according to the theoretical imperatives and conventions of the present moment.

Butler is so keen to distance her discussions of vulnerability from equating women with victimhood, that she is unable to think vulnerability without it being correlated with resistance: 'women are at once vulnerable and capable of resistance', in fact 'vulnerability and resistance can, and do, and even must happen at the same time' (2015: 141). Moreover, despite her recognition of the different ways that vulnerability can be distributed, analytically the universal corporeal vulnerability takes priority:

Though we may legitimately feel that we are vulnerable in some instances and not in others, the condition of our vulnerability is itself not changeable. This does not mean that we are objectively or subjectively equally vulnerable all the time. But it does mean that it is a more or less implicit or explicit feature of our existence (2015: 150).

Butler acknowledges a more politicised account of the distribution of vulnerability is available, but this is not her concern. Even in Notes Toward a Performative Theory of Assembly published more than a decade after Precarious Life, she is still appealing to vulnerability as a motif by which we can rethink social relations on a global scale.

Yet the problematic implications of such an ambivalent, universal account for feminism are evident. As a universal, the experiences of particular women and individuals are obscured. By presenting it as ambivalent and coupling it with resistance, the vulnerability of the many women who cannot or do not resist in Butler's terms (through the formation of 'certain forms of feminist self-defence and institutions' (2015: 141)) are 
rendered invisible. This is something that a politics of sexual violence knows only too well. Vulnerability as susceptibility to harm is a key iteration of the term that pertains to certain social relations of inequality. Moreover, Butler does in fact use the term in precisely this way in her earlier book Bodies that Matter (1993). Turning to this text exposes the inadequacy of a progress narrative that receives corporeal vulnerability as a redemptive account of the concept.

\section{vii. The Vulnerability of Venus Xtravaganza}

If one turns to the breadth of Butler's work, one particular use of the term that is illuminating and, I gesture, that might expose the limitations of corporeal vulnerability for feminism is in her discussion of Venus Xtravaganza in Bodies That Matter (1993). In this earlier text, Butler uses the term 'vulnerable' in its common dictionary sense of 'susceptibility to harm'. Analysing the documentary Paris is Burning, Butler regards the fate of Venus Xtravaganza, a Latina male to female transgender drag ball performer who earnt a living as prostitute so that she could save up enough money for sex reassignment surgery. Butler asks us to

...consider the different fates of Venus Xtravaganza. She 'passes' as a light skinned woman, but is - by virtue of a certain failure to pass completely - clearly vulnerable to homophobic violence; ultimately, her life is taken presumably by a client who, upon the discovery of what she calls her 'little secret', mutilates her for having seduced him. On the other hand Willi Ninja can pass as straight... (2011: 89).

As Butler understands it, Venus dies because she cannot pass completely, whereas Willi Ninja, a gay male choreographer and dancer, can pass as straight. They are both approximating the norm of straightness, yet Willi succeeds and thus is highly successful in his life, whereas Venus' 'truth' is uncovered and so she is killed. Vulnerability here is neither ambivalent nor universal. Rather, it is highly politically charged.

Butler's explanation of Venus' death is misguided: I would suggest that the violence that Venus is subject to is not simply homophobic violence but a much more complex amalgam of homophobia, sexism and transphobia. As Viviane Namaste explains, on Butler's reading 'Gender is thus a vehicle that functions to displace the material and symbolic conditions of race and class' (2005: 214) and this leads her to elide Venus' transsexual status. Moreover, it is too much of a leap to ignore altogether another 
difference between Willi Ninja and Venus; their gender. Butler's failure to recognise that Venus' death also mirrors the deaths of many women who make a living selling sex: trans, cis, white, Latina and the myriad of other stratifications of women, exposes the limits of her analysis. However, what is instructive here is the urgency of an application of vulnerability as susceptibility to harm. Venus' vulnerability is not simply a product of homophobia, but a complex intersection of social structures. Nevertheless, the corporeal vulnerability that is a shared condition of Venus and her clientmurderer, is of little relevance compared to the relative vulnerability that leads to Venus' death. This is a phenomenon that Butler fleetingly acknowledges in Precarious Life when she says that 'women and minorities, including sexual minorities, are, as a community, subjected to violence, exposed to its possibility, if not its realization' (2004: 20). Yet the specificity of the violence that these groups are exposed to, and the ensuing vulnerability is left unexplored by Butler whose main concern since 2004 has been providing a minimal basis for a global ethics of nonviolence.

\section{viii. Ethics and Politics}

The problem for feminism with disassociating vulnerability from a discussion of sexual violence, is that its critical, political potential is elided. No doubt there is a risk of reproducing and sustaining the very structures and relations that one seeks to address and Butler fears turning a sociological, historically contingent claim into one that is descriptive and serves to reproduce those very power relations. However, it must be possible to articulate a politics of vulnerability without being always already implicated in accusations of victimisation and essentialism.

Whilst Butler recognises that 'there are radically different ways in which human physical vulnerability is distributed across the globe' (2004b: $24)$, for the most part this varying vulnerability is equated with grievability: those whose lives are not grievable are more vulnerable. Thus there are those for whom there is no public grieving; the apprehension of a common vulnerability does not extend to these lives in such a way that would render them grievable. However, as Estelle Ferrarese astutely notes, Judith Butler 'does not really succeed in establishing a politics of vulnerability' (2016: 226) and 'in her discussion of vulnerability, the political dimension is primarily located in the issue of the widening of the range of lives which are considered as lives and made recognizable as such' (2016: 227). Hence her focus on the universality of vulnerability; it is a mechanism for widening the domain of liveable lives.

Whilst I am not advocating a 'return' to past articulations of the 
concept, I am concerned that a reception of Butler's approach to vulnerability as the enlightened moment in the term's history, depends on a rejection of vulnerability and its connection to sexual violence altogether. Butler says that 'women have too long been associated with vulnerability and there is no clear way to derive an ethics, much less a politics, from that notion' (2015: 123). Regarding ethics, one might agree. Concerning politics on the other hand, Butler is too quick to dismiss the contributions of feminists before her. Griselda Pollock calls for a nonlinear and non-teleological understanding of history which would resist thinking of the future as what comes out of a necessary overcoming of the past by the present, by allowing different temporalities (the lingering, the emergent, the not yet there etc.) to coexist (Berger 2016: 17). Perhaps we can do the same for vulnerability. Rather than replacing sexual politics with universal ethics, violence with ambivalence, perhaps the different formulations can exist alongside one another, provoking and complicating one another, rather than one superseding one another. As Renée Heberle and Victoria Grace contend, 'an enduring feminist aim is, without doubt, the redress and amelioration of women's vulnerability to violence in various forms' (2011: 8). Focussing on the universality of vulnerability, as the condition of possibility for a global ethics, occludes rather than reveals the experiences of gendered lives. The point is not that corporeal vulnerability is inadequate, but rather that it is a mistake to treat it as an exhaustive theory of vulnerability.

\section{ix. Concluding Remarks}

Corporeal vulnerability has emerged as a pivotal concept for feminist ethics. It enables us to rethink our ties to others, challenges a masculinist individualism by presenting the subject as constituted by these very ties and entails wide reaching ethical responsibilities. Moreover, it accomplishes this all whilst being inherently inclusive and non-essentialising. However, to treat it as a new, exhaustive 'theory' of vulnerability depends upon the reduction and dismissal of an entire body of work, without sufficient engagement. Despite emanating from the fact of embodied existence, corporeal vulnerability is unable to distinguish between the way that certain bodies may be differentially lived as or rendered vulnerable; as was the case with Venus Xtravaganza. Thus corporeal vulnerability is best situated alongside, rather than against prior articulations of the concept within feminist thought. 
Emily Cousens is a PhD Candidate at Oxford Brookes University and lecturer at Oxford Brookes University and The University of Hertfordshire. Her research explores Feminism and the Politics of Vulnerability and she has written on related matters for mainstream publications such as The Independent and has also appeared on radio discussing applications of her research. Emily is the Founder of the London Free School of Applied Critical and Feminist Theory, an intimate feminist summer school that charges no fees whatsoever for students and fosters a non-hierarchical space for learning outside of the imperatives of institutionalised academia. She completed both her BA in Philosophy, Politics and Economics and MA in Women's Studies at The University of Oxford.

\section{Bibliography}

Benhabib, S. (1994) 'In Defense of Universalism. Yet Again! A Response to Critics of Situating the Self' New German Critique (62), 173-189

Berger, A. (2016) 'Gender Springtime in Paris: A Twenty-First-Century Tale of Seasons' Differences 27(2), 1-26.

Brownmiller, S. (1975) Against our will: Men, women, and rape London:

Secker \& Warburg.

Browne, V. (2014) 'The persistence of patriarchy: Operation Yewtree and the return to 1970s Feminism' Radical Philosophy 188. pp. 9-20

Butler, J. (2004a) Precarious life: the powers of mourning and violence London: Verso

Butler, J. (2004b) Undoing gender New York; London: New York ; London : Routledge

Butler, J. (2006) Gender trouble: feminism and the subversion of identity New York; London: New York ; London : Routledge

Butler, J. (2010) Frames of war: when is life grievable? London: Verso

Butler, J. (2011) Bodies that matter: on the discursive limits of sex London: London: Routledge 
Butler, J. (2015) Notes toward a performative theory of assembly Cambridge, Massachusetts: Harvard University Press.

Detloff, M. (1997) 'Mean Spirits: The Politics of Contempt between Feminist Generations' Hypatia 12(3), 76-99

Ferrarese, E. (2016) 'Vulnerability: A Concept with Which to Undo the World As It Is?' Critical Horizons: A Journal of Philosophy and Social Theory 17(2), 149-159

Fraser, N. (1989) Unruly practices: power, discourse and gender in contemporary social theory Oxford: Oxford: Polity

Fraser, N. (2013) Fortunes of feminism: from state-managed capitalism to neoliberal crisis London: Verso Books

Gilson, E. C. (2014) The ethics of vulnerability: a feminist analysis of social life and practice New York: Routledge

Gutterman, D. and Rushing, S. (2008) 'Sovereignty and suffering: towards an ethics of grief in a post- 9/11 world' in Carver, T. \& Chambers, S. A. ed. Judith Butler's Precarious Politics: Critical Encounters London: Routledge.

Halberstam, J. (2015) 'Straight Eye for the Queer Theorist- A Review of "Queer Theory Without Antinormativity"' Available online at: https://bullybloggers.wordpress.com/2015/09/12/straight-eye-for-thequeer-theorist-a-review-of-queer-theory-without-antinormativity-by-jackhalberstam/ [Accessed 28.11.2017]

Heberle, R. \& Grace, V. (2011) Theorizing sexual violence New York; London: New York; London : Routledge

Hekman, S. (2014) 'Vulnerability and Ontology: Butler's Ethics' Australian Feminist Studies 29(82),

$452-464$

Hemmings, C. (2005) ‘Telling feminist stories' Feminist Theory 6(2), 115-139

Hemmings, C. (2011) Why stories matter: the political grammar of feminist theory Durham, NC: Durham, NC: Duke University Press 
Lloyd, M. (2007) Judith Butler: from norms to politics Cambridge: Cambridge: Polity

Mardorossian, C M. (2002) 'Toward a New Feminist Theory of Rape' Signs 27(3), 743-775

Millett, K. (1977). Sexual politics London: Virago

Millett, K. (2000). Sexual politics Urbana: University of Illinois Press

Murphy, A. V. (2012) Violence and the philosophical imaginary Albany: Albany: State University of New York Press

Namaste, V. K. (2005) Sex change, social change: reflections on identity, institutions and imperialism. Toronto, Ont. Women's Press.

Petherbridge, D. (2016). What's Critical about Vulnerability? Rethinking Interdependence, Recognition, and Power. Hypatia,31(3), 589-604.

Riley, D. (1988). 'Am I that name?': Feminism and the category of 'women' in history (Language, discourse, society series) Basingstoke: Macmillan

Schippers, B. (2014) The political philosophy of Judith Butler New York: Routledge

Shulman, G. (2011). 'On Vulnerability as Judith Butler's Language of Politics: From Excitable Speech to Precarious Life' WSQ: Women's Studies Quarterly 39(1), 227-235

Watson, J. (2012) ‘Butler's Biopolitics: Precarious Community' Theory \& Event 15(2)

Wiegman, R. (2012) Object lessons Durham, NC: Duke University Press

\section{Endnotes}

${ }^{1}$ This has led to her being critiqued for an over association of vulnerability with violence (Murphy, 2011; Petherbridge, 2016) 